\title{
A CASE STUDY OF CAIRO INTERNATIONAL AIRPORT “CIA": PROPOSED INSTALLATION OF PHOTOVOLATIC "PV" FOR HIGH ENERGY-PRODUCTION
}

\author{
MOHAMED S. EMEARA ${ }^{\mathbf{1}}$, AHMED FAROUK ABDELGAWAD ${ }^{2}, \boldsymbol{\&}$ AHMED H. EL ABAGY \\ ${ }^{I}$ Mechanical Power Engineering Dept., Faculty of Engineering, Zagazig University, Zagazig 44519, Egypt \\ ${ }^{2}$ Mechanical Power Engineering Dept., Faculty of Engineering, Zagazig University, Zagazig 44519, Egypt \\ ${ }^{3}$ Mechanical Power Engineering Dept., Faculty of Engineering, Zagazig University, Zagazig 44519, Egypt
}

\begin{abstract}
Airports play a pivotal role in the global air transport industry. The increase in passenger and air cargo traffic has led to increase of energy requirements. Airports have introduced a wide range of energy saving procedures. Solar technology is growing rapidly at airports. Solar energy reduces the airport operating costs, and has environmental benefits such as cleaner air and fewer greenhouse gases. Building Information Modeling "BIM" is a software tool that uses a relational database with a behavioral model to represent the building information dynamically. Using BIM helps with the urgent aspects of sustainability design, e.g., solar analysis. Also, BIM can perform yearly sun studies to define when the building is provided with natural shading. Furthermore, BIM can then reduce the capacity of cooling systems, and explaining the building is exceeding the baseline building energy requirements. This paper aims to reduce the energy consumption by proposing the installation of renewable energy Photovoltaic "PV" solar system. The performance is simulated by the Autodesk Revit, PVsyst software, and supported by theoretical calculations. The studied results can produce a high annual energy production of about 22,000 MWh/yr and reduce a considerable annual amount of carbon dioxide $\left(\mathrm{CO}_{2}\right)$, which represents 15,000 tons $/ y$ r.

KEYWORDS: Cairo International Airport, Solar Energy, BIM, PV, Autodesk Revit, PVsyst
\end{abstract}

Received: Oct 01, 2020; Accepted: Oct 20, 2020; Pbublished: Nov 10, 2020; Paper Id.: IJMPERDOCT202040

\section{INTRODUCTION}

The awareness of the impact of the built environment on the natural environment is still increasing. In the last years, the use of sustainable and green building concepts has developed very rapidly (Lawrence, Darwich, \& Means, 2018, pp. 3-17). Energy is essential to advancing economic development and growing living standards. Majority of energy consumption for electricity, heating and cooling, and transportation is supplied by fossil fuels combustion. Energy used by the aircraft is needed over all phases of operations (International Civil Aviation Organization ICAO, 2017, pp. 3-39). As airport's electricity is typically provided by the electric grid, the development of on-site electricity principally minimizes the request for off-site power (Whiteman, et al., 2015, pp. 7-39). Accordingly, airports systems have a high electrical-energy request due to the requirements of airport buildings and facilities such as terminal air conditioning, pre-conditioned air and power at gates, powering of many equipment, and other special airport systems (International Civil Aviation Organization ICAO, 2015, pp. 6-14).

\subsection{History}

\subsubsection{Airport Renewable Energy Case Studies}

In this section, some famous case studies are mentioned as examples of utilization of renewable energy in airports. 
Seymour Airport: Managed by the Argentinian company Ecogal S.A. located on Baltra Island, the airport consumes 35\% of its energy demand from solar PV panels (International Civil Aviation Organization ICAO, 2017, pp. 42-52). George Airport: In September 2015, George Airport became the first airport in Africa to draw power from renewable energy. It has 3,000 PV modules, with a nameplate capacity of $750 \mathrm{~kW}$, which meets $41 \%$ of the airport's electricity needs (International Civil Aviation Organization ICAO, 2017, pp. 42-52). Kansai International Airport: Kansai Airport in Osaka, Japan has developed varied renewable energy projects. In 2014, it launched an 11.6 MW CIS (Copper, Indium, Selenium) installation. The system produces annually about 12 million $\mathrm{kWh}$ of electricity (International Civil Aviation Organization ICAO, 2017, pp. 42-52).

\subsubsection{Building Information Modeling (BIM) background}

The Associated General Contractors of America defines BIM as a smart and parametric digital representation to create information can be used to give decisions and improve the process (Jung et al., 2013). BIM reflects and affirms the process sides (Sacks, Eastman, Lee, \& Teicholz, 2018, pp. 12-24). Thus, BIM maturity in 1990s was CAD, using drawings, lines, text, etc., and the tools were papers. In 2000s, using 2D and 3D models, the tools were file-based collaboration. In 2010s, the tools of BIM were files and libraries. In 2020s, BIM is developing to be Building Lifecycle Management to use Integrated Interoperable Data, and tools are Integrated Web Services BIM Hub (Sacks, Eastman, Lee, \& Teicholz, 2018, pp. 12-24).

\subsection{Motivation}

\subsubsection{PV Technology Features}

There are various distinct features associated with using solar PV modules as follows: (1) It is relatively easy to modify the size of a system; simply by increasing or decreasing the number of solar panels (International Civil Aviation Organization ICAO, 2017, pp. 3-39). (2) It can feasibly be deployed on any stable, earthly place and produce electricity as all land receives some sunlight that can be turned into electricity (International Civil Aviation Organization ICAO, 2017, pp. 3-39).

(3) The amount of electricity that will be generated by a solar facility for any specific location can be easily predicted based on existing knowledge of climate conditions (International Civil Aviation Organization ICAO, 2017, pp. 3-39).

\subsubsection{Importance of BIM}

Generally, there are many benefits of using BIM as: Concept, feasibility, and design benefits: An approximate or aggregate building model incorporated into and connected to a cost database can be of enormous value. Increased building performance and quality: Developing a schematic model previously to create a detailed building model specifically for a more accurate evaluation to define if it meets the building's functional, sustainability, and other requirements. Improvement of energy efficiency and sustainability: Linking the building model to energy analysis tools gives evaluation of energy and provides many chances to develop building quality (Sacks, Eastman, Lee, \& Teicholz, 2018, pp. 12-24). BIM has the ability to achieve a more energy-efficient building (Abanda, \& Byers, 2019).

\subsubsection{Autodesk Revit Software}

Revit is a renowned BIM platform, created by Autodesk in 2002. Revit is a major fit for the analysis for sustainable design. Revit enables model check, energy simulation and other analyses, connectivity of Mechanical, Electrical and Plumbing systems, modeling or geometry discrepancies, and annotation graphics (Sacks, Eastman, Lee, \& Teicholz, 2018, pp. 70$85)$. 


\subsubsection{PVsyst Software}

PVsyst offers results in the form of a full report, defined graphs tables, and data can be exported to be used in other software (Sacks, Eastman, Lee, \& Teicholz, 2018, pp. 70-85). PVsyst is one of the best simulation software to evaluate the performance of a solar PV power plant. On a case study of Cochin International Airport, PVsyst software was found to match closely with actual site data (Sukumaran, \& Sudhakar, 2017). PVsyst is able to estimate the performance of grid connected, stand-alone and DC solar systems based on the defined module and selected location (Sukumaran, \& Sudhakar, 2017).

\section{RESEARTH METHODOLOGY}

\subsection{Present Case Study}

The aim of the present research is the reduction of energy consumption of Cairo International Airport-Terminal Building No. 02 "CIA-TB2" from the utility grid by installing renewable energy solar PV panels. The simulation software used for the study of PV energy production are Autodesk Revit, and PVsyst, and the results are supported with theoretical calculations.

\subsection{Data Collection}

Based on the data of ("Cairo Airport, " n.d.), ("Cairo International Airport," 2020) and ("CAI Google Earth, " 2020). CIA is consisted of the following: (1) Terminal Building 01 "CIA-TB1". (2) Terminal Building 02 "CIA-TB2". (3) Terminal Building 03 "CIA-TB3". (4) Seasonal Flight Terminal. (5) CIA Control Tower. (6) Parking Area. (7) Cairo Airport Hotel. (8) Parking Building. (9) CIA-TB3 Power \& Cooling Plant. (10) CIA-TB2 Power Plant. (11) CIA Fire Fighting Building.

Thus, Cairo International Airport-Terminal Building No. 02 "CIA-TB2" is consisted of the following ("CAI Google Earth, " 2020): (1) Building A "BL-A". (2) Building B "BL-B". (3) Building C "BL-C". (4) Passenger Boarding Bridge Buildings, Qty. 11 Buildings. (5) CIA-TB2 Power Plant. (6) Taxiway Area. (7) Airside Area. (8) Landscape Areas.

\subsection{Assumed Values of Energy Consumption for CIA}

As many of the required data for the present research are not openly available, it is a must to assume them. These data concern mainly the values of energy consumption and $\mathrm{CO} 2$ emissions. First, the data of CIA Terminals are presented. Then, data of other selected International Airports are presented. Accordingly, the values of the energy consumption of CIA can be assumed.

\subsubsection{CIA Terminals Data}

CIA-TB1 has 12 gates ("Cairo International Airport," 2020). CIA-TB2 total terminal area is $230 \mathrm{~m}^{2}$ ("Cairo International Airport," 2016), which was designed for a capacity 7.5 million passengers per year ("Cairo International Airport," 2020). TB2 has 14 gates and an additional 5 remote stands ("Cairo International Airport," 2020). CIA-TB3 total terminal area is 211,000 $\mathrm{m}^{2}$, which was designed for a capacity of 11 million passengers per year ("Cairo International Airport," 2008). TB3 has 23 gates ("Cairo International Airport," 2020). Seasonal Flight Terminal serves about 3.2 million passengers per year with 27 check-in counters and 7 gates ("Cairo International Airport," 2020). 


\subsubsection{Data of Other Selected International Airports and values of Energy Consumption}

Kansai Airport: Terminal-1 has a total floor area 303,944 $\mathrm{m}^{2}$ and Terminal-2 has a total area 29,680 $\mathrm{m}^{2}$ (Baxter, Srisaeng, \& Wild, 2018). In 2016, 25.2 million passengers used the airport. The annual electricity consumption is $122,000 \mathrm{MWh}$ in 2002. Achieved many sustainable works and reduced this amount to be 102,000 MWh in 2015 (Baxter, Srisaeng, \& Wild, 2018). Copenhagen Airport: The airport received close to 30.3 million passengers in 2019 ("Copenhagen Airport, " 2020). The annual electricity consumption is about $115,000 \mathrm{MWh}$ in 2010 with $\mathrm{CO}_{2}$ emissions are 27,707 tons. Achieved many sustainable works and reduced these quantities in 2013 to be about 95,000 MWh and 24,557 tons (Baxter, Srisaeng, \& Wild 2015). Hartsfield-Jackson Atlanta International Airport: The airport has terminals and concourses totaling 630,000 m² ("Hartsfield-Jackson Atlanta International, " 2020). The airport serves more than 100 million passengers in a single year ("About ATL, " n.d.). The airport required over 240,220 MWh of electricity in 2010 (Hartsfield-Jackson Atlanta International Airport, 2011).

\subsubsection{Assumed values for CIA}

After presenting all the previous useful data for the international airports, values of electricity consumption and $\mathrm{CO}_{2}$ emissions for Cairo Airport can be assumed (estimated) as shown in Table 1.

Table 1: Assumed Energy Consumption Values for CIA Buildings \& Areas.

\begin{tabular}{|l|c|c|}
\hline \multicolumn{1}{|c|}{ Cairo International Airport } & $\begin{array}{c}\text { Assumed Values of } \\
\text { Electricity Consumption } \\
\text { (kWh/yr) }\end{array}$ & $\begin{array}{c}\text { Assumed Values of } \\
\text { CO }_{\mathbf{2}} \text { Emissions } \\
\text { (tons/yr) }\end{array}$ \\
\hline CIA-TB1 & $40,000,000$ & 26,000 \\
\hline CIA-TB2 & $48,000,000$ & 30,000 \\
\hline CIA-TB3 & $70,000,000$ & 51,000 \\
\hline CIA Seasonal Flight Terminal & $20,000,000$ & 15,000 \\
\hline CIA Control Tower & $6,000,000$ & 3,900 \\
\hline CIA Hotel & $10,000,000$ & 5,100 \\
\hline CIA-TB3 Power \& Cooling Plant & $7,000,000$ & 9,600 \\
\hline CIA-TB2 Power Plant & 290,000 & 2,800 \\
\hline CIA Fire Fighting Building & 150,000 & 1,800 \\
\hline CIA Parking Building & 170,000 & 4,200 \\
\hline CIA Parking Area & 150,000 & 4,000 \\
\hline Total & $\mathbf{2 0 1 , 7 6 0 , 0 0 0}$ & $\mathbf{1 8 3 , 4 0 0}$ \\
\hline
\end{tabular}

\subsection{Calculation Methods}

In the present research, the objective results are found by using three different methods of calculation for integration and reliability. These methods are as follows: (1) Using theoretical calculation. (2) Autodesk Revit software. (3) PVsyst software.

\subsubsection{Theoretical Calculations}

For the calculation of the solar energy output of a PV system, using the following ("Solar radiation databases, " n.d.):

$$
\mathrm{E}=\mathrm{A} \times \mathrm{r} \times \mathrm{H} \times \mathrm{PR}
$$


Where, $\mathrm{E}=$ Energy $\quad(\mathrm{kWh}) . \mathrm{A}=$ Total solar panel area $\left(\mathrm{m}^{2}\right) . \mathrm{r}=$ Solar panel yield $(\%)=\mathrm{PV}$ panel $\mathrm{kW} /$ panel area. $\mathrm{H}=$ Annual average irradiation on tilted panels. PR = Performance ratio, i.e., coefficient for losses (range between 0.9 and 0.5 , default value $=0.75$ ). The yearly-sum of global irradiance on Egypt is 2,000 kWh/m² ("Photovoltaic software, " n.d.).

\subsubsection{Autodesk Revit software}

By using this software, two main simulation reports of solar analysis can be given: (1) PV energy production and energy savings. (2) Irradiance Insolation and Global Horizontal Irradiance (GHI).

\subsubsection{PVsyst Software}

This software gives results in the form of a full report, specific graphs, and tables. Thus, data can be exported for use in other software codes ("PVsyst software, " n.d.).

\subsection{Significant Parameters and Indicators}

There are some important parameters and indicators that are used in the present calculations, which can be listed as: (1) PV Energy Production: The total value of energy generated by the PV System and the output "O/P" unit is $\mathrm{kWh} / \mathrm{yr}$. (2) Irradiance Insolation: The amount of power is the product of the power $\left(1000 \mathrm{~W} / \mathrm{m}^{2}\right)$ times the time length (1 hour), so that the unit of energy is the kWh. (3) Global Horizontal Irradiance (GHI) or (GlobHor): It is the total amount of shortwave radiation received from above by a surface horizontal to the ground. (4) Performance Ratio (PR): PR indicates the effect of losses on the power output of a PV power plant during DC to AC conversion. (5) Tilt Angle "Elevation Angle": It describes the vertical angle of the solar panels. (6) Azimuth Angle: It is their horizontal facing in relation to the Equator. On PVsyst, the azimuth zero corresponds to the south. For instance, 215 deg that is between South and South West, therefore the azimuth angle is $35^{\circ}$ ("PVsyst Help. PVsyst, " n.d.). (7) Saved Amount of $\mathbf{C O}_{\mathbf{2}}$ : The yearly savings of $\mathrm{CO}_{2}$ emissions, given in tons. A direct formula can be used to calculate the saved amounts of PV System (i.e., 0.000684 tons/kWh) (Armbrester et al., 2008, pp. 47-48)

\subsection{Creating CIA Model by Autodesk Revit Software}

Autodesk Revit software is a significant tool for sustainable design and analysis (Jung et al., 2013). It enables energy simulation and daylight analysis using accurate model location, and weather data file (Jung et al., 2013). After collecting the data, the model is created by Revit with running "Solar Analysis". Figure 1 illustrates CIA on Google Earth ("CAI Google Earth, " 2020) and the created model is shown in Figure 2.

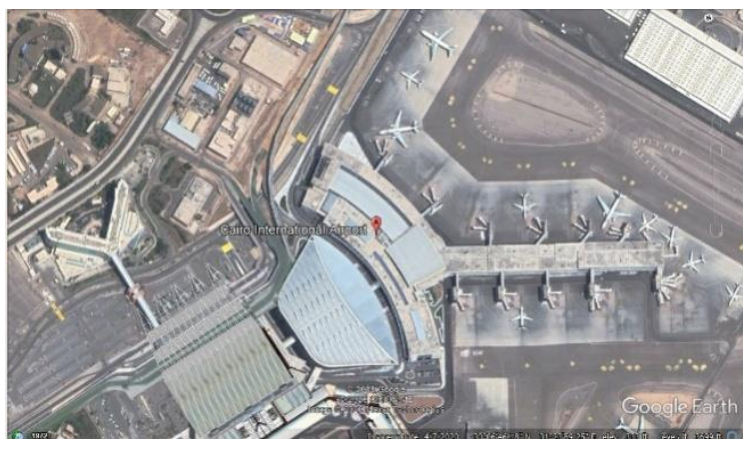

Figure 1: CIA-TB2, CIA-TB3, and CIA parking area view on Google Earth ("CAI Google Earth, " 2020).

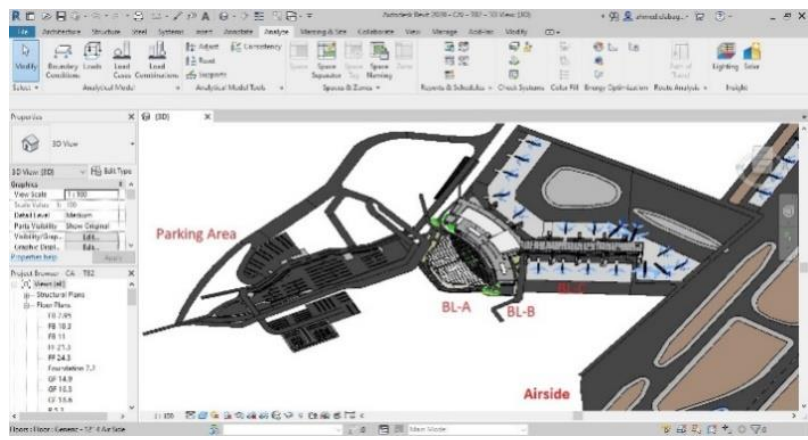

Figure 2: Created model by Autodesk Revit software for CIA-TB2 and CIA Parking Area. 


\section{RESULTS}

In this section, the calculations are presented for Irradiance Insolation and for PV Energy Production using PV panel 320 W and $408 \mathrm{~W}$ by using Autodesk Revit software, and using PV panel $320 \mathrm{~W}$ and $410 \mathrm{~W}$ by using PVsyst software. Also, results of the theoretical calculations are demonstrated.

\subsection{Results by Autodesk Revit Software}

After creating the model, "Solar Analysis" can be applied for a selected area. Revit software gives values for Irradiance Insolation and Global Horizontal Irradiation. Also, it can offer the values of PV Energy Production and Energy Savings.

\subsubsection{Irradiance Insolation and Global Horizontal Irradiation}

Table 2 shows the complete values by Autodesk Revit over the year for CIA TB2 -BL-C Roof, Area 14,154 m², BL-B Roof, Area 19,568 m², and Parking Area 122,582 m².

Table 2: Solar Analysis Over the year by Autodesk Revit Software for CIA TB2 -BL-C Roof, Area 14,154 m², BL-B Roof, Area 19,568 m², and Parking Area 122,582 $\mathrm{m}^{2}$.

\begin{tabular}{|c|c|c|c|c|c|c|c|}
\hline \multirow[b]{2}{*}{$\begin{array}{c}\text { Case } \\
\text { Method }\end{array}$} & \multirow[b]{2}{*}{ Month } & \multicolumn{2}{|c|}{ BL-C Roof } & \multicolumn{2}{|c|}{ BL-B Roof } & \multicolumn{2}{|c|}{ Parking Area } \\
\hline & & $\begin{array}{c}\text { Irradiation } \\
\text { Insolation } \\
\quad(\mathbf{k W h})\end{array}$ & $\begin{array}{c}\text { Global } \\
\text { Horizonta } \\
\text { Irradianc } \\
\text { e } \\
\left(\mathbf{k W h} / \mathbf{m}^{2}\right)\end{array}$ & $\begin{array}{l}\text { Irradiation } \\
\text { Insolation } \\
(\mathbf{k W h})\end{array}$ & $\begin{array}{c}\text { Global } \\
\text { Horizonta } \\
\text { Irradiance } \\
\left(\mathbf{k W h} / \mathbf{m}^{2}\right)\end{array}$ & $\begin{array}{c}\text { Irradiatio } \\
\text { Insolation } \\
\quad(\mathbf{k W h})\end{array}$ & $\begin{array}{c}\text { Global } \\
\text { Horizontal } \\
\text { Irradiance } \\
\left(\mathbf{k W h} / \mathbf{m}^{2}\right)\end{array}$ \\
\hline Case 1.1 & January & $1,274,251.00$ & 90 & $1,566,802.00$ & 80.00 & $10,730,578.00$ & 88.00 \\
\hline Case 1.2 & February & $1,316,555.00$ & 93 & $1,631,075.00$ & 83.00 & $11,095,812.00$ & 91.00 \\
\hline Case 1.3 & March & $2,102,584.00$ & 149 & $2,628,986.00$ & 134.00 & $17,721,587.00$ & 145.00 \\
\hline Case 1.4 & April & $2,411,293.00$ & 170 & $3,033,372.00$ & 155.00 & $20,297,583.00$ & 166.00 \\
\hline Case 1.5 & May & $2,838,793.00$ & 201 & $3,582,283.00$ & 183.00 & $23,861,558.00$ & 195.00 \\
\hline Case 1.6 & June & $2,938,634.00$ & 208 & $3,711,323.00$ & 190.00 & $24,687,174.00$ & 201.00 \\
\hline Case 1.7 & July & $2,969,401.00$ & 210 & $3,749,581.00$ & 192.00 & $24,947,026.00$ & 204.00 \\
\hline Case 1.8 & August & $2,740,875.00$ & 194 & $3,452,962.00$ & 176.00 & $23,064,303.00$ & 188.00 \\
\hline Case 1.9 & September & $2,302,377.00$ & 163 & $2,887,515.00$ & 148.00 & $19,395,562.00$ & 158.00 \\
\hline Case 1.10 & October & $1,796,267.00$ & 127 & $2,233,952.00$ & 114.00 & $15,139,818.00$ & 124.00 \\
\hline Case 1.11 & November & $1,268,336.00$ & 90 & $1,562,355.00$ & 80.00 & $10,689,457.00$ & 87.00 \\
\hline Case 1.12 & December & $1,136,712.00$ & 80 & $1,394,604.00$ & 71.00 & $9,571,037.00$ & 78.00 \\
\hline Year & & $25,096,078.00$ & $1,775.00$ & $31,434,810.00$ & $1,606.00$ & $211,201,495.00$ & $1,725.00$ \\
\hline
\end{tabular}

\subsubsection{PV Energy Production and Energy Savings}

This section gives the results of energy production and savings using different proposed PV panels. First: using PV panel $320 \mathrm{~W}$ Figure 3 shows the simulation results for the roof of Building C. Second: using PV panel 408 W. Table 3 shows the Simulation Energy Production and Energy Savings by Autodesk Revit software using PV panel $320 \mathrm{~W}$ and $408 \mathrm{~W}$. 


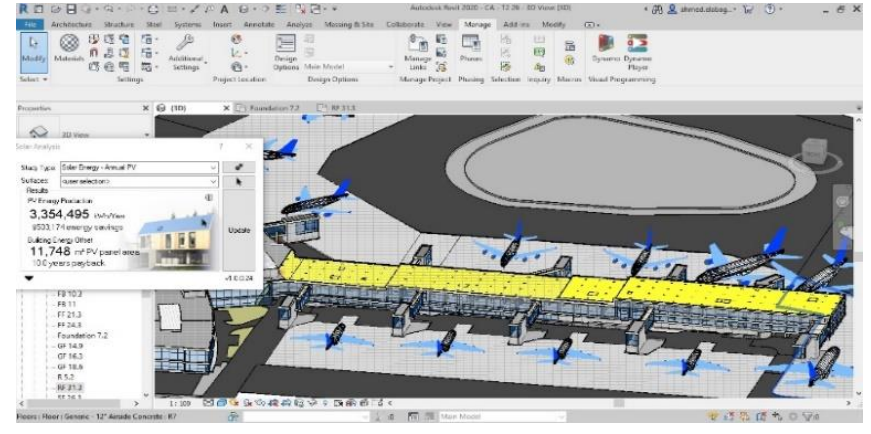

Figure 3: The Solar Analysis Simulation by Autodesk Revit for CIA TB2 - BL-C Roof, PV Panel 320 W.

\begin{tabular}{|c|c|c|c|c|c|}
\hline PVSYST 7.0.2 & & & & $25 / 06 / 20$ & Page $2 / 4$ \\
\hline \multicolumn{6}{|c|}{ Grid-Connected System: Main results } \\
\hline Project : & CAI TB2 - BL-C Roof & & & & \\
\hline Simulation variant: & New simulation variant & & & & \\
\hline Main system parameters & System type & № $3 \mathrm{D}$ scene defined, & d, no shadings & & \\
\hline PV Field Orientation & tilt & $27^{\circ}$ & azimuth & $0^{\circ}$ & \\
\hline PV modules & Model & JKM 320PP-72 (Plus) & Pnom & $320 \mathrm{Wp}$ & \\
\hline PV Array & $\mathrm{Nb}$. of modules & 6052 & Pnom total & $1937 \mathrm{~kW}$ & \\
\hline Inverter & Model & PVS800-57-0630kW-B & B Pnom & $630 \mathrm{~kW} \mathrm{a}$ & \\
\hline $\begin{array}{l}\text { Inverter pack } \\
\text { User's needs }\end{array}$ & $\begin{array}{l}\text { Nb. of units } \\
\text { Unlimited load (grid) }\end{array}$ & 3.0 & Pnom total & $1890 \mathrm{~kW}$ & \\
\hline $\begin{array}{l}\text { Main simulation results } \\
\text { System Production }\end{array}$ & $\begin{array}{r}\text { Produced Energy } \\
\text { Performance Ratio PR }\end{array}$ & $\begin{array}{l}3306 \mathrm{MWh} / \text { year } \\
82.25 \%\end{array}$ & Specific prod. & $1707 \mathrm{~kW}$ & Wh/kWp/year \\
\hline
\end{tabular}

Figure 4: Sample Report of Simulation Result by PVsyst for CIA TB2 - BL-C Roof, PV Panel 320 W.

Table 3: Revit Simulation of Energy Production and Energy Savings Using PV Panel 320 W and 408 W.

\begin{tabular}{|c|c|c|c|c|c|c|c|}
\hline \multirow[b]{2}{*}{$\begin{array}{c}\text { Building / } \\
\text { Area }\end{array}$} & \multirow{2}{*}{$\begin{array}{c}\text { PV } \\
\text { Panel } \\
\text { Area } \\
\left(\mathbf{m}^{2}\right)\end{array}$} & \multicolumn{3}{|c|}{ PV panel $320 \mathrm{~W}$} & \multicolumn{3}{|c|}{ PV panel $408 \mathrm{~W}$} \\
\hline & & $\begin{array}{c}\text { Case } \\
\text { Method }\end{array}$ & $\begin{array}{c}\text { Production } \\
\text { Energy } \\
(\mathbf{k W h} / \mathbf{y r})\end{array}$ & $\begin{array}{l}\text { Saving } \\
\text { Power } \\
\text { (EGP) }\end{array}$ & $\begin{array}{c}\text { Case } \\
\text { Method }\end{array}$ & $\begin{array}{c}\text { Production } \\
\text { Energy } \\
(\mathrm{kWh} / \mathrm{yr})\end{array}$ & $\begin{array}{l}\text { Saving } \\
\text { Power } \\
\text { (EGP) }\end{array}$ \\
\hline $\mathrm{BL}-\mathrm{C}$ & 11,478 & Case 1.37 & $3,354,495$ & $7,547,610$ & Case 1.51 & $4,276,981$ & $9,623,205$ \\
\hline BL-B & 15,067 & Case 1.38 & $4,237,019$ & $9,533,295$ & Case 1.52 & $5,402,199$ & $12,154,950$ \\
\hline Parking & 34,323 & Case 1.39 & $9,815,759$ & $22,083,540$ & Case 1.53 & $12,515,093$ & $28,158,960$ \\
\hline PBB-01 & 74 & Case 1.40 & 19,600 & 44,100 & Case 1.54 & 24,990 & 56,235 \\
\hline PBB-02 & 84 & Case 1.41 & 22,450 & 50,520 & Case 1.55 & 28,624 & 64,410 \\
\hline PBB-03 & 71 & Case 1.42 & 20,280 & 45,630 & Case 1.56 & 25,857 & 58,185 \\
\hline PBB-04 & 94 & Case 1.43 & 25,255 & 56,820 & Case 1.57 & 32,200 & 72,450 \\
\hline PBB-05 & 94 & Case 1.44 & 26,256 & 59,070 & Case 1.58 & 33,476 & 75,315 \\
\hline PBB-06 & 84 & Case 1.45 & 23,867 & 53,700 & Case 1.59 & 30,431 & 68,475 \\
\hline PBB-07 & 84 & Case 1.46 & 23,708 & 53,340 & Case 1.60 & 30,228 & 68,010 \\
\hline PBB-08 & 82 & Case 1.47 & 23,028 & 51,810 & Case 1.61 & 29,361 & 66,060 \\
\hline PBB-09 & 124 & Case 1.48 & 35,176 & 79,140 & Case 1.62 & 44,850 & 100,905 \\
\hline PBB-10 & 99 & Case 1.49 & 27,561 & 62,010 & Case 1.63 & 35,140 & 79,065 \\
\hline PBB-11 & 108 & Case 1.50 & 30,759 & 69,210 & Case 1.64 & 39,218 & 88,245 \\
\hline
\end{tabular}

\subsection{Results by PVsyst software}

- Setting up the required inputs: By using the collected data and data of the created CIA model by Revit into PVsyst as follows: Choosing geographical site: to get location and weather data. Setting up orientation data (Tilt angle and Azimuth angle) for the PV modules. Selecting the system data: Define PV panel area. Select PV module (Type and PV power). Select inverter (Type, operating voltage and output voltage). Design the array: Review for the number for modules and strings.

- Run Simulation: Get the report for the output values: Produced Energy. Performance Ratio (PR). Graphs for the produced energy and performance ratio. Simulation tables of results over the year (e.g., GHI, ambient temperature, effective energy and PR): First using PV panel 320 W Run simulation for defined PV panel areas for CAI-TB2 Buildings. Figure 4 shows sample report of simulation result. Second using PV panel 410 W. Table 4 shows the simulation results. 
Table 4: PVsyst Simulation Results of Energy Production and Performance Ratio Using PV Panel $320 \mathrm{~W}$ and $410 \mathrm{~W}$.

\begin{tabular}{|c|c|c|c|c|c|c|c|c|}
\hline \multirow[b]{2}{*}{$\begin{array}{c}\text { Case } \\
\text { Method }\end{array}$} & \multirow[b]{2}{*}{$\begin{array}{l}\text { Building } \\
\text { / Area }\end{array}$} & \multirow{2}{*}{$\begin{array}{c}\text { PV } \\
\text { panel } \\
\text { Area } \\
\left(\mathbf{m}^{2}\right)\end{array}$} & \multicolumn{3}{|c|}{ PV panel $320 \mathrm{~W}$} & \multicolumn{3}{|c|}{ PV panel $410 \mathrm{~W}$} \\
\hline & & & $\begin{array}{l}\text { Productio } \\
\text { n Energy } \\
(\mathbf{k W h} / \mathbf{y r})\end{array}$ & PR & $\begin{array}{c}\text { Saving } \\
\mathrm{CO}_{2} \\
\text { (tons/yr) } \\
\end{array}$ & $\begin{array}{l}\text { Productio } \\
\text { n Energy } \\
(\mathrm{kWh} / \mathrm{yr})\end{array}$ & PR & $\begin{array}{c}\text { Saving } \\
\mathrm{CO}_{2} \\
\text { (tons/yr) }\end{array}$ \\
\hline Case 2.1 & BL-C & 11,478 & $3,306,000$ & 0.833 & 2,261 & $4,154,000$ & 0.837 & 2,841 \\
\hline Case 2.2 & BL-B & 15,067 & $4,501,000$ & 0.832 & 3,079 & $5,354,000$ & 0.840 & 3,662 \\
\hline Case 2.3 & Parking & 34,323 & $9,262,000$ & 0.847 & 6,335 & $11,693,000$ & 0.847 & 7,998 \\
\hline Case 2.4 & PBB-01 & 74 & 20,500 & 0.812 & 14 & 25,600 & 0.836 & 18 \\
\hline Case 2.5 & PBB-02 & 84 & 20,800 & 0.824 & 14 & 24,200 & 0.836 & 17 \\
\hline Case 2.6 & PBB-03 & 71 & 19,698 & 0.824 & 13 & 21,200 & 0.832 & 15 \\
\hline Case 2.7 & PBB-04 & 94 & 25,500 & 0.800 & 17 & 28,200 & 0.830 & 19 \\
\hline Case 2.8 & PBB-05 & 94 & 25,700 & 0.807 & 18 & 28,200 & 0.830 & 19 \\
\hline Case 2.9 & PBB-06 & 84 & 20,800 & 0.824 & 14 & 24,200 & 0.836 & 17 \\
\hline Case 2.10 & PBB-07 & 84 & 20,600 & 0.815 & 14 & 28,300 & 0.832 & 19 \\
\hline Case 2.11 & PBB-08 & 82 & 22,400 & 0.803 & 15 & 28,200 & 0.830 & 19 \\
\hline Case 2.12 & PBB-09 & 124 & 34,000 & 0.812 & 23 & 42,800 & 0.838 & 29 \\
\hline Case 2.13 & PBB-10 & 99 & 27,700 & 0.819 & 19 & 34,200 & 0.836 & 23 \\
\hline Case 2.14 & PBB-11 & 108 & 29,200 & 0.815 & 20 & 36,300 & 0.836 & 25 \\
\hline
\end{tabular}

\subsection{Results by Theoretical Calculations}

Eq. (1) is used to calculate the solar PV energy output for the two selected PV panels: First using PV panel 320 W Calculate the PV energy output for CIA-TB2 Buildings. Second using PV panel $410 \mathrm{~W}$. Table 5 shows the calculations results.

Table 5: Calculation the Oretical Results of PV Energy Output by Using PV Panel 320 W and 410 W.

\begin{tabular}{|c|c|c|c|c|c|c|}
\hline \multirow{2}{*}{$\begin{array}{c}\text { Case } \\
\text { Method }\end{array}$} & \multirow{2}{*}{$\begin{array}{c}\text { Building / } \\
\text { Area }\end{array}$} & \multirow{2}{*}{$\begin{array}{c}\text { PV panel } \\
\text { Area } \\
\left(\mathbf{m}^{2}\right)\end{array}$} & $\begin{array}{c}\text { Production } \\
\text { Energy } \\
(\mathbf{k W h} \mathbf{y r})\end{array}$ & $\begin{array}{c}\text { Saving } \\
\text { Power } \\
(\mathbf{E G P})\end{array}$ & $\begin{array}{c}\text { Production } \\
\text { Energy } \\
(\mathbf{k W h} / \mathbf{y r})\end{array}$ & $\begin{array}{c}\text { Saving Power } \\
(\mathbf{E G P})\end{array}$ \\
\hline Case 3.1 & BL-C & 11,478 & $3,059,576$ & $6,884,045$ & $3,938,905$ & $8,862,537$ \\
\hline Case 3.2 & BL-B & 15,067 & $4,011,438$ & $9,025,736$ & $5,189,075$ & $11,675,418$ \\
\hline Case 3.3 & Parking & 34,323 & $9,302,906$ & $20,931,538$ & $11,919,348$ & $26,818,533$ \\
\hline Case 3.4 & PBB-01 & 74 & 19,228 & 43,263 & 25,364 & 57,070 \\
\hline Case 3.5 & PBB-02 & 84 & 22,149 & 49,836 & 28,792 & 64,782 \\
\hline Case 3.6 & PBB-03 & 71 & 18,721 & 42,123 & 24,220 & 54,494 \\
\hline Case 3.7 & PBB-04 & 94 & 24,064 & 54,144 & 31,988 & 71,973 \\
\hline Case 3.8 & PBB-05 & 94 & 24,275 & 54,618 & 31,988 & 71,973 \\
\hline Case 3.9 & PBB-06 & 84 & 22,149 & 49,836 & 28,792 & 64,782 \\
\hline Case 3.10 & PBB-07 & 84 & 21,907 & 49,291 & 28,654 & 64,472 \\
\hline Case 3.11 & PBB-08 & 82 & 21,071 & 47,409 & 27,905 & 62,785 \\
\hline Case 3.12 & PBB-09 & 124 & 32,220 & 72,495 & 42,604 & 95,859 \\
\hline Case 3.13 & PBB-10 & 99 & 25,946 & 58,378 & 33,933 & 76,350 \\
\hline Case 3.14 & PBB-11 & 108 & 28,166 & 63,374 & 37,018 & 83,291 \\
\hline
\end{tabular}

\section{DISCUSSIONS}

After applying the three methods of calculations by Autodesk Revit, PVsyst, and theoretical calculations for two types of PV Panels ( $320 \mathrm{~W}$ and $410 \mathrm{~W}$ ). Tables 6 summarizes the calculation results for PV panel 320 and $410 \mathrm{~W}$, also can be seen the average values for the calculated results of PV panel $410 \mathrm{~W}$. Figures 5-8 illustrate the summarized calculation results. 
Table 6: Summarized Calculation Results for PV Panel 320 and 410 W.

\begin{tabular}{|c|c|c|c|c|c|c|c|c|c|}
\hline \multirow[b]{2}{*}{$\begin{array}{l}\text { Building } \\
\text { / Area }\end{array}$} & \multirow[b]{2}{*}{$\begin{array}{c}\text { PV Panel } \\
\text { Area } \\
\left(\mathrm{m}^{2)}\right.\end{array}$} & \multicolumn{4}{|c|}{ Production Energy using PV panel 320 W } & \multicolumn{4}{|c|}{ Production Energy using PV panel 410 W } \\
\hline & & $\begin{array}{c}\text { Autodesk } \\
\text { Revit } \\
\text { (kWh/yr) }\end{array}$ & $\begin{array}{c}\text { PVsyst } \\
(\mathbf{k W h} / \mathbf{y r})\end{array}$ & $\begin{array}{l}\text { Theoretical } \\
\text { Calculation } \\
(\mathbf{k W h} / \mathbf{y r})\end{array}$ & $\begin{array}{c}\text { Average } \\
\text { Prod. } \\
\text { Energy } \\
(\mathbf{k W h} / \mathbf{y r})\end{array}$ & $\begin{array}{c}\text { Autodesk } \\
\text { Revit } \\
(\mathbf{k W h} / \mathbf{y r})\end{array}$ & $\begin{array}{c}\text { PVsyst } \\
(\mathbf{k W h} / \mathbf{y r})\end{array}$ & $\begin{array}{c}\text { Theoretical } \\
\text { Calculation } \\
(\mathbf{k W h} / \mathbf{y r})\end{array}$ & $\begin{array}{c}\text { Average } \\
\text { Prod. } \\
\text { Energy } \\
(\mathbf{k W h} / \mathbf{y r})\end{array}$ \\
\hline $\mathrm{BL}-\mathrm{C}$ & 11,478 & $3,354,495$ & $3,306,000$ & $3,059,576$ & $3,240,024$ & $4,276,981$ & $4,154,000$ & $3,938,905$ & $4,123,295$ \\
\hline BL-B & 15,067 & $4,237,019$ & $4,501,000$ & $4,011,438$ & $4,249,819$ & $5,402,199$ & $5,354,000$ & $5,189,075$ & $5,315,091$ \\
\hline Parking & 34,323 & $9,815,759$ & $9,262,000$ & $9,302,906$ & $9,460,222$ & $12,515,093$ & $11,693,000$ & $11,919,348$ & $12,042,480$ \\
\hline PBB-01 & 74 & 19,600 & 20,500 & 19,228 & 19,776 & 24,990 & 25,600 & 25,364 & 25,318 \\
\hline PBB-02 & 84 & 22,450 & 20,800 & 22,149 & 21,800 & 28,624 & 24,200 & 28,792 & 27,205 \\
\hline PBB-03 & 71 & 20,280 & 19,698 & 18,721 & 19,566 & 25,857 & 21,200 & 24,220 & 23,759 \\
\hline PBB-04 & 94 & 25,255 & 25,500 & 24,064 & 24,940 & 32,200 & 28,200 & 31,988 & 30,796 \\
\hline PBB-05 & 94 & 26,256 & 25,700 & 24,275 & 25,410 & 33,476 & 28,200 & 31,988 & 31,221 \\
\hline PBB-06 & 84 & 23,867 & 20,800 & 22,149 & 22,272 & 30,431 & 24,200 & 28,792 & 27,808 \\
\hline PBB-07 & 84 & 23,708 & 20,600 & 21,907 & 22,072 & 30,228 & 28,300 & 28,654 & 29,061 \\
\hline PBB-08 & 82 & 23,028 & 22,400 & 21,071 & 22,166 & 29,361 & 28,200 & 27,905 & 28,489 \\
\hline PBB-09 & 124 & 35,176 & 34,000 & 32,220 & 33,799 & 44,850 & 42,800 & 42,604 & 43,418 \\
\hline PBB-10 & 99 & 27,561 & 27,700 & 25,946 & 27,069 & 35,140 & 34,200 & 33,933 & 34,424 \\
\hline PBB-11 & 108 & 30,759 & 29,200 & 28,166 & 29,375 & 39,218 & 36,300 & 37,018 & 37,512 \\
\hline Total & & $17,685,213$ & $17,335,898$ & $16,633,816$ & $17,218,310$ & $22,548,648$ & $21,522,400$ & $21,388,586$ & $21,819,877$ \\
\hline
\end{tabular}

Figure 5 shows the summarized Production Energy results using PV panel $320 \mathrm{~W}$ for Building C Roof, Building B Roof, and Parking Area. It is clear that the results by Autodesk Revit, PVsyst, and theoretical calculations are very close to the average values for Building C, Building B and Parking Area. Similarly for PBB Buildings using PV panel 320 W as been shown on Figure 6. Figure 7 explains the summarized Production Energy results using PV panel $410 \mathrm{~W}$ for Building C Roof, Building B Roof, and Parking Area. The results by Autodesk Revit, PVsyst, and theoretical calculations are very close to the average values. Figure 8 displays the summarized Production Energy results using PV panel 410 W for PBB Buildings. It can also be shown that the results of other PBB Buildings are close to the average values. Briefly, Figures 5-8 confirm that the results of these calculation methods are very accurate. Moreover, Autodesk Revit, and PVsyst can be used in the design phase of installing PV energy.

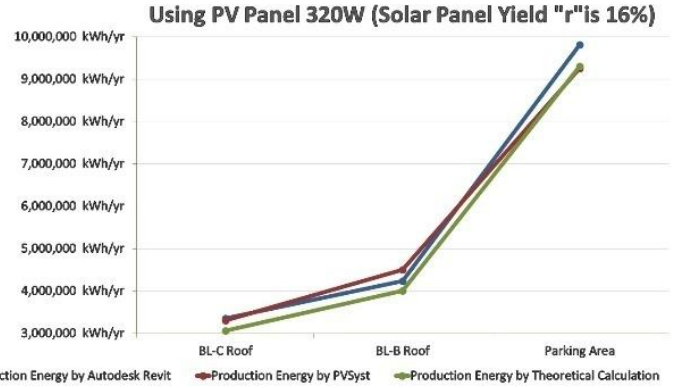

Figure 5: Summarized Production Energy results using PV panel $320 \mathrm{~W}$ for CIA-TB2 (BL-C, BL-B and Parking).

$13,000,000 \mathrm{kWh} / \mathrm{rr}$
$12,000,000 \mathrm{kWh} / \mathrm{rr}$

$11,000,000 \mathrm{kWh} / \mathrm{r}$

$9,000,000 \mathrm{kWh} / \mathrm{yr}$

$8,000,000 \mathrm{kWh} / \mathrm{rr}$

$7,000,000 \mathrm{kWh} / \mathrm{rr}$

$6,000,000 \mathrm{kWh} / \mathrm{yr}$

$5,000,000 \mathrm{kWh} / \mathrm{yr}$

$4,000,000 \mathrm{kWh} / \mathrm{sr}$

Using PV Panel 410W (Solar Panel Yield " $r$ "is 20.5\%)

$\rightarrow$ Production Energy by Autodesk Revit $\rightarrow$ Production Energy by PVSyst $\rightarrow$ Production Energy by Theoretical Calculation

Figure 7: Summarized Production Energy results using PV panel $410 \mathrm{~W}$ for CIA-TB2 (BL-C, BL-B and Parking).
Using PV Panel 320W (Solar Panel Yield " $r$ "is 16\%)

$40,000 \mathrm{kWh} / \mathrm{r}$

$35,000 \mathrm{kWh} / \mathrm{rr}$

$30,000 \mathrm{kWh} / \mathrm{yr}$

$25,000 \mathrm{kWh} / \mathrm{yr}$

$20,000 \mathrm{kWh} / \mathrm{yr}$

$15,000 \mathrm{kWh} / \mathrm{yr}$

$10,000 \mathrm{kWh} / \mathrm{yr}$

$5,000 \mathrm{kWh} / \mathrm{yr}$

$0 \mathrm{kWh} / \mathrm{yr}$

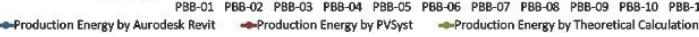

Figure 6: Summarized Production Energy results using PV panel $320 \mathrm{~W}$ for CIA-TB2 PBB Buildings.

Using PV Panel 410W (Solar Panel Yield "r"is 20.5\%)

$50,000 \mathrm{kWh} / \mathrm{yr}$

$45,000 \mathrm{kWh} / \mathrm{s}$

$40,000 \mathrm{kWh} / \mathrm{rr}$

$35,000 \mathrm{kWh} / \mathrm{r}$

$25,000 \mathrm{kWh} / \mathrm{yr}$

$20,000 \mathrm{kWh} / \mathrm{rr}$

$15,000 \mathrm{kWh} / \mathrm{rr}$

$10,000 \mathrm{kWh} / \mathrm{N}$

$5,000 \mathrm{kWh} / \mathrm{rr}$

$0 \mathrm{kWh} / \mathrm{s}$

Figure 8: Summarized Production Energy results using PV panel $410 \mathrm{~W}$ for CIA-TB2 PBB Buildings. 


\section{CONCLUSIONS}

This paper studied the consumption energy of Cairo International Airport and the possibility of using PV Solar Energy to reduce the electricity consumption and $\mathrm{CO}_{2}$ emissions for Terminal Building 2. Thus, the prominent conclusions drawn are:

- $\quad$ PV panel $410 \mathrm{~W}$ is highly recommended to be used.

- It is possible to get a high annual production energy (about 22,000 MWh/yr) and reducing a large annual amount of $\mathrm{CO}_{2}$ (About 15,000 tons/yr).

- The planned results can save around $45 \%$ of the consumed energy per year (Producing about 22,000 MWh/yr from the consumption energy 48,000 MWh/yr).

- Large roof and parking areas can be used for installing PV solar system and getting a high energy production.

- The PV performance results using simulation software (Autodesk Revit and PVsyst) is found to be very close to each other and also is close to theoretical results.

\section{REFERENCES}

1. Lawrence, T., Darwich, A.K., \& Means, J.K. (2018). ASHRAE Green Guide Design, Construction, and Operation of Sustainable Buildings (5th ed.). Atlanta: American Society of Heating, Refrigerating and Air-Conditioning Engineers ASHRAE

2. International Civil Aviation Organization ICAO. (2017). Renewable Energy for Aviation: Practical Applications to Achieve Carbon Reductions and Cost Savings. Montreal, Canada: ICAO

3. Whiteman, A., Bannard, D., Smalinsky, T., Korovesi I., Plante J., \& T. DeVault, T. (2015). Airport Cooperative Research Program ACRP Report No. 141: Renewable Energy as an Airport Revenue Source. Washington, D.C.: The National Academies of Sciences Engineering Medicine

4. Jung, D., Lee, D., Shin, J., Song, B., \& Park, S. (2013). Optimization of energy consumption using BIM-based building energy performance analysis. Applied Mechanics and Materials, vol. 281, 649-652. https://doi.org/10.4028/www.scientific.net/AMM.281.649

5. Sacks, R., Eastman, C., Lee, G., \& Teicholz, P. (2018). BIM Handbook A Guide to Building Information Modeling for Owners, Designers, Engineers, Contractors, and Facility Managers (3rd ed.). New Jersey: John Wiley \& Sons, Inc

6. Abanda, F.H., \& Byers, L. (2019). An Investigation of the Impact of Building Orientation on Energy Consumption in a Domestic Building Using Emerging BIM (Building Information Modelling). International Journal of Advanced Research and Publications IJARP, vol. 3, no. 6, 517-520. https://doi.org/10.1016/j.energy.2015.12.135

7. Sukumaran, S., \& Sudhakar, K. (2017). Fully solar powered airport: A case study of Cochin International airport. Journal of Air Transport Management, vol. 62, 176-188. https://doi.org/10.1016/j.jairtraman.2017.04.004

8. Cairo Airport. (n.d.). Retrieved July 1, 2020 from https://www.cairo-airport.com/en-us/

9. Cairo International Airport. (2020). Retrieved July 1, 2020 from https://en.wikipedia.org/wiki/Cairo_International_Airport

10. Cairo International Airport (CAI), Google Earth. (2020). Retrieved July $1, \quad 2020 \quad$ from https://earth.google.com/web/search/Cairo+International+Airport+(CAI)

11. Cairo International Airport Terminal 3. (2008). Retrieved July 1, 2020 from https://tavconstruction.com/aviation-projects 
12. Cairo International Airport Terminal Building No. 2, Renovation and Expansion, Egypt. (2016). Retrieved July 1, 2020 from http://www.limak.com.tr/sectors/construction/projects/projects-completed/airports/cairo-international-airport-terminalbuilding-no2-renovation-and-expansion-egypt

13. Baxter, G., Srisaeng, P., \& Wild, G. (2018). Sustainable Airport Energy Management: The Case of Kansai International Airport. International Journal for Traffic and Transport Engineering, vol. 8, no. 3, 334-358. https://doi.org/10.7708/ijtte.2018.8(3).07

14. Copenhagen Airport. (2020). Retrieved July 1, 2020 from https://en.wikipedia.org/wiki/Copenhagen_Airport

15. Baxter, G., Srisaeng, P., \& Wild, G. (2015). Sustainable Airport Energy Management: A Case Study of Copenhagen Airport. International Symposium on Sustainable Aviation, 1-4. 10.13140/RG.2.1.1163.2806

16. Hartsfield-Jackson Atlanta International Airport. (2020). Retrieved July $1, \quad 2020 \quad$ from https://en.wikipedia.org/wiki/Hartsfield\%E2\%80\%93Jackson_Atlanta_International_Airport

17. About ATL, Hartsfield-Jackson Atlanta International Airport. (n.d.). Retrieved July 1, 2020 from http://www.atl.com/about-atl/

18. Hartsfield-Jackson Atlanta International Airport. (2011). Sustainable Management Plan. Atlanta: Hartsfield-Jackson Atlanta International Airport

19. Solar radiation databases, Photovoltaic software. (n.d.). Retrieved June 1, 2020 from https://photovoltaicsoftware.com/principle-ressources/solar-radiation-databases

20. Photovoltaic software. (n.d.). Retrieved June 1, 2020 from https://photovoltaic-software.com/

21. PVsyst software. (n.d.). Retrieved July 1, 2020 from https://www.PVsyst.com/

22. PVsyst Help. PVsyst. (n.d.). Retrieved July 1, 2020 from https://www.PVsyst.com/help

23. Armbrester, B., Borin, S., Choi, D. G., Fernandez, A., Gumm, T., Tindall, N., \& Wang, J. (2008). Sustainability Options at the Hartsfield-Jackson Atlanta International Airport. Georgia: Georgia Institute of Technology 
